\title{
EVALUATION OF GOVERNANCE STRUCTURE IN SOYBEAN VALUE CHAIN IN NIGER STATE OF NIGERIA
}

\author{
Lukman B.O. ${ }^{1 *}$, Bwala M.A. ${ }^{2}$, Baba K C. ${ }^{2}$, Dauda S.N. ${ }^{1}$, Yunusa J.B. ${ }^{1}$ \\ ${ }^{1}$ National Cereals Research Institute Badeggi, Niger State, Nigeria \\ ${ }^{2}$ Department of Agricultural Economics and Extension Services, Faculty of Agriculture, \\ Ibrahim Badamasi Babangida University, Lapai, Niger State, Nigeria \\ *E-mail: lukzynan2003@yahoo.com
}

\begin{abstract}
This research was carried out to evaluate the presence and nature of governance structure in soybean value chain in Niger state of Nigeria. Multistage sampling procedure was used for this study. Firstly, purposive sampling was used in the selection of six Local Government Areas (LGAs) out of the 25 LGAs in Niger State. The LGAs are Lapai, Paiko, Mariga, Mashegu, Mokwa and Shiroro. The second stage involved selection of three communities randomly from each Local Government selected for the study. This brings about a total of 18 communities for the study. The communities are; Samunaka, Takalafia, Zolegi, Beri, Kampani Bobi, Mariga, Kaboji, Baban Rami, Karmi Rami, Muregi, Tatabo, Nwogi, Paiko, Pago, Dagonagbe, Gunu, Kope and Nakomi. The third stage involved the determination of sample size from the sample frame using the formula cited by Robert V., Krejcie and Daryle W. Morgan (1963) stated as $S=X^{2} N P(1-P) \div d^{2}(N-1)+X^{2} P(1-P)$. Primary data was obtained through the use of structured questionnaires. The study used descriptive statistics and Tobit regression model for relevant analyses. The results show the presence of market governance. The production and processing segments of the nods analysed are found to be porous with minimal entry and exit conditions.
\end{abstract}

\section{KEY WORDS}

Soya bean, governance, public policy, production.

Soya bean is specie of legume that has its origin traced to East Asia. Soya bean is a fat free cheap source of protein to both human and animals. Soya beans are also known to be rich in calcium, fiber, iron, magnesium, and some other enriching vitamins and minerals. Soya bean is a versatile source of food as it can be cooked, fermented, dried, and converted into products like milk, flour, tofu and more (Steve, 2017). Soya bean is grown largely for its edible bean which has several uses. The plant is categorized as an oil seed rather than a pulse by the Food and Agricultural Organization (FAO). Soya bean is a major source of vegetable protein and oil in the world. Worldwide demand continues to be high and production has more than doubled in the past 20 years to a total of 264.2 million metric tons in 2011 (National Agricultural Statistics Service, 2012).

The modern concept of value chain cannot be conceptualized without mentioning Micheal Porter. Inarguably, Micheal Porter was the first scholar to bring value chain to a front burner in 1985 (Elvira, 2016). He described value chain as an effective way to examine the interaction among different players in a given industry (Brown, 1997). The concept is often used to describe the full range of activities which are required to bring a product or service from conception, through the different phases of production, distribution to consumers and final disposal after use. As a product moves from one player in the chain to another, it is assumed to gain a value (Hellin and Meijer, 2006). According to Fearne, Martinez and Dent (2012), value chain is highly applicable to differentiated products and segmented markets.

Governance in value chain is the power which any party may have in the chain may paradoxically be reflected in two seemingly contradictory attributes (Raphael, 2000). The first arise from the power to force other parties to take particular actions, this can be noticed where some parties are limited to assembling and are not allowed to involve in the design. The second may also show in the capacity of players to be unresponsive to the demands of 
others. This is where a party refuses to confinement rule that may be imposed on it. These opposing effects also arise from the fact that parties are often involved in different value chains and these may result in cross-cutting power between value chains with the demands of one dominating the other with detrimental effects down the chain (Gereffi \& Kaplinsky, 2001).

Value chain governance can also refer to the relationship between the buyers, sellers, service providers and regulatory institution that operate within or influence the range of activities required to bring product or service from inception to its end use (Humphery and Schmitz, 2008).

Three major warnings to note in expatiating governance in value chain analysis are:

- Some value chains exhibit very little governance at all, or at best very thin forms of governance;

- In most value chains there are multiple points of governance (in all three areas of legislative, judicial and executive governance). At any one point in time, a number of different parties may be setting rules (which may differ in nature), auditing performance and assisting producers to achieve the required standards. These parties may be from within the chains themselves or in the local community or in business associations. There may thus be overlaps between vertical and horizontal forms of governance.

Some chains may embody both producer- and buyer-driven governance. For example, in clothing the effectiveness of a governor's command of a chain does not only reflect the power of its sanctions, but also the trust which its suppliers or customers have in it. This is particularly important in assessing the long-term viability of the chain. There is of course an extensive literature on trust, much of it theoretical in nature (Humphrey and Schmitz, 1996). A distinction is made between two types of governance: thus, cases where the coordination is undertaken by buyers ('buyer-driven commodity chains') and those in which producers play the key role ('producer-driven commodity chains'), (Humphrey and Schmitz, 1996).

The following types of behaviour in relation to value chain actors can be used to evaluate the availability, type(s) and degree of governance in place.

- the length of contracts;

- the nature of the ordering procedure;

- the nature of the contractual relationship;

- the modes of inspection used in accepting incoming materials;

- the degree of dependence which firms have on each other;

- the types of technical assistance which flows along the chain;

- the nature and methods of communication along the chain;

- the determination of prices;

- the nature of credit extended along the chain especially to exporting firms;

- the modalities of payment to outsourced informal economy producers.

It is pertinent to bear in mind that all the parameters must not necessarily be applied at the same. Selecting the relevant parameters depend on the material and methods to be applied in the analysis.

Value chain governance can take five forms. These are market, modular, relational, captive and hierarchy (Humphrey, 2008).

- Market governance involves transactions that are relatively simple, information on product specifications is easily transmitted, and producers can make products with minimal input from buyers;

- Modular governance arises when a product needs the firm in the chain to carry out complex transactions that are relatively easy to codify;

- Relational governance is when the interaction between buyers and sellers are characterized by the transfer of information and embedded services based on mutual reliance regulated through reputation, social and spatial proximity, family and ethnic ties, and the like; 
- Captive governance occurs when small suppliers are dependent on a few buyers that often exercise a great deal of power and control. This is usually characterized by high degree of monitoring and control by the lead firm;

- Hierarchy governance concentrates on chains that are characterized by vertical integration and managerial control within a set of lead firm that develops and manufactures products in-house. This occurs when product specification cannot be codified (Humphery and Schmitz, 2008).

\section{MATERIALS AND METHODS OF RESEARCH}

This study used primary data which was obtained through a well-structured questionnaire administered by trained enumerators. A Multistage sampling technique will be used for this study. Niger state is an emerging state in terms of soybeans production in Nigreria. Niger State has three agricultural zones, thus; Zone 1 (Niger-South), Zone 2 (NigerCentral) and Zone 3 (Niger-East) with twenty five (25) Local Government Areas (LGAs). Two (2) Local Government Areas will be purposively selected from each agricultural zone in Niger State. These local government areas are Mokwa and Lapai, Shiroro and Paikoro, Mariga and Mashegu from agricultural Zone 1, Zone 2 and Zone 3 of Niger state respectively. These LGAs are known for soybean production according to National Cereals Research Institute (NCRI) 2018 report. The second stage will involve selection of three (3) communities randomly from each selected Local Government Area. This will give a total of eighteen (18) communities to be considered in this study. The third stage will involve determination of sample frame for the study, after which sample determination formula as cited by Robert V., Krejcie and Daryle W. Morgan's article (1963) will be used to arrive at the sample size.

$S=X^{2} N P(1-P) \div d^{2}(N-1)+X^{2} P(1-P)$ will be used to arrive at the sample size for the study, where: $S=$ required sample, $X^{2}=$ the table value of chi-square for 1 degree of freedom at the desired confidence level (3.841), $\mathrm{N}=$ the population size, $\mathrm{P}=$ the population proportion (assumed to be 0.5 since this could provide the maximum size), $d=$ the degree of accuracy expressed as a proportion (0.05).

Assessment parameters include;

- the nature of the ordering procedure;

- the degree of dependence which firms have on each other;

- the types of technical assistance which flows along the chain;

- the nature and methods of communication along the chain;

- the determination of prices;

- entry and exit requirement(s) of the chain.

Tobit regression analysis was used for all the qualitative response parameters. According to Hisayuki (2008), Tobit model is the model in which econometricians only observe dependent variables that satisfy some restrictions.

Explicitly, the standard Tobit model for this study is stated as:

$$
y_{i}^{*}=x_{i} \beta+\varepsilon_{i}
$$

The dependent variable $y_{i}^{*}$ is determined by $y_{i}=$ as $y_{i}^{*}$ : if $y_{i}^{*}>L, 0$ : if $y_{i}^{*} \leq L, y_{i}^{*}$ is a latent variable which is not observed, $X_{i}$ is a row vector of regressors (independent variables as defined above) which include the constant; where: $X_{1=}$ Self (personal choice), $X_{2}=$ producer union, $X_{3}=$ buyers, $X_{4}=$ government/agency and $X_{5=}$ market forces, $\varepsilon_{i}=$ disturbance term, $L=$ is a constant threshold value which needs not be known and could be zero. Descriptive statistical techniques were also used to describe the data collected where necessary.

\section{RESULTS AND DISCUSSION}

The result of the field survey as it is highlighted in table 1 below shows that there is relatively weak dominance by any determinant of governance in value chain analysis. Hence, the 
available governance structure in the chain is that of "Market Governance". This is true due to the fact that the decision of when to sell and how much to sell lies largely on the individual actor. The manifestation of relationship governance is weak with only about $8 \%$ on when to sell and $7 \%$ on how much to sell. The percentage of the players enjoying such symbiotic interaction is considered weak, hence relationship governance cannot be adjudged. The fact that there is no domination of any interest ruled out captive governance. The interplay of market information and knowledge also helps to boost the market governance in place.

Table 1 - Summary of Relational Interaction among Determinants of Governance

\begin{tabular}{llc}
\hline $\begin{array}{l}\text { Decision Index } \\
\text { When to sell }\end{array}$ & Frequency & Percentage (\%) \\
Personal Choice & 172 & 92 \\
Producers' Union & 53 & 28.3 \\
Buyers & 15 & 8.0 \\
Government \& other agencies & 1 & 0.5 \\
How much to sell & 147 & 78.6 \\
Personal Choice & 49 & 26.2 \\
Producers' union & 13 & 7.0 \\
Buyers & 1 & 0.5 \\
Government \& other agencies & 30 & 16 \\
Market forces & & \\
\hline
\end{tabular}

Source: Field Survey 2021.

The result of the Tobit regression analysis carried out shows that buyers and government \& other agencies are significant at $5 \%$. This is clearly shown in table 2 (result of Tobit regression model analysis on the determinants of choice of selling time) below.

Table 2 - Determinants of Choice of Selling Time

\begin{tabular}{lcccc}
\hline & Determinants & & \\
Parameter & Self (personal choice) & producer union & buyers & government/agency \\
\hline Coef. & -9.287332 & -1.612052 & -30.17645 & -84.61869 \\
Std. Err. & 16.16692 & 9.767793 & 14.31405 & 37.6925 \\
$\mathrm{t}$ & -0.57 & -0.17 & $-2.11 *$ & $-2.24 *$ \\
$\mathrm{p}>|\mathrm{t}|$ & 0.566 & 0.869 & 0.036 & 0.026 \\
$*=$ significant at $5 \%(0.05) * *=$ significant & &
\end{tabular}

Source: Data analysis 2021.

Tobit regression model was also used to evaluate those factors that influence the decision on how much to sell. From the result, both buyers and market forces are significant at $5 \%$. This is clearly shown on the table below (table 3 ) which is the Tobit regression model analysis result.

Table 3 - Determinants of Choice of Selling Price

\begin{tabular}{lccccc}
\hline & \multicolumn{2}{c}{ Determinants } & & & \\
Parameter & Self (personal choice) & producer union & buyers & government/agency & market forces \\
\hline Coef. & -9.875474 & -16.72489 & 43.55672 & -69.09433 & -29.06369 \\
Std. Err. & 12.66378 & 12.16493 & 15.3943 & 52.97345 & 11.01973 \\
$\mathrm{t}$ & -0.78 & -1.37 & $-2.83 *$ & -1.30 & $-2.64^{*}$ \\
$\mathrm{p}>\mathrm{t} \mid$ & 0.437 & 0.171 & 0.005 & 0.194 & 0.009 \\
\hline$*=$ significant at $5 \%(0.05),{ }^{* *}=$ significant at $1 \%(0.01)$. & & &
\end{tabular}

Source: Data analysis 2021. 
Production Participation Index (Requirement). This study carried out a push to know how porous the production segment of soybean value chain is, the result is summarized in the table 4 below. From the table, it can be seen clearly that production technical-know-how is the major prerequisite for participation in this segment. This is so because about $74.9 \%$ (140) of the respondents affirmed to that. While about $24.6 \%$ (46) of the respondents stated that they require application through a working body to be able to participate in the production nod of soybean value chain. This shows that there is weak entry and exit mechanism in place.

Table 4 - Production Participation Index

\begin{tabular}{lcc}
\hline Index & Frequency & Percentage (\%) \\
a. Applying through Union & 46 & 24.6 \\
b. Knowledge (Technical-know-how) & 140 & 74.9 \\
c. Application and Knowledge (a \& b) & 1 & 0.5 \\
\hline
\end{tabular}

Source: Field Survey 2021.

\section{CONCLUSION}

The result of the study shows that there is presence of market governance in soybean value chain in the study area. The presence of relevant cooperative/union does not translate in strong cohesion in decision making among the actors in the chain. The production and processing segments of the nods are characterized by limited entry requirement. The nods are also found to be porous as entry into the market requires mainly the relevant technicalknow-how required in the production and processing.

Processors are advised to form a formidable union for promotion of their interest and enhance access to government and corporate bodies. The porous nature of the production and processing segments (nods) of the chain calls for concern most especially when standard is to be maintained. The poor participation of wholesalers in soybean value chain in the study area speaks volume of market and business opportunity in that segment.

\section{APPENDIX}

\begin{tabular}{|c|c|c|c|c|c|c|c|}
\hline \multicolumn{4}{|c|}{$\begin{array}{l}\text { Tobit regression } \\
\text { Log } 1 \text { ikelihood }=-1003.1463\end{array}$} & \multicolumn{2}{|c|}{$\begin{array}{l}\text { Number of obs } \\
\text { LR chi2(4) } \\
\text { Prob }>\text { chi2 } \\
\text { Pseudo R2 }\end{array}$} & \multirow{2}{*}{$\begin{array}{l}= \\
= \\
= \\
= \\
\text { onf. }\end{array}$} & \multirow{2}{*}{$\begin{array}{r}187 \\
9.67 \\
0.0464 \\
0.0048 \\
\end{array}$} \\
\hline whodecides 1 & coef. & Std. Err. & $\mathrm{t}$ & $P>|t|$ & {$[95 \% \mathrm{C}$} & & \\
\hline $\begin{array}{r}\text { selfperson e } \\
\text { producersu n } \\
\text { buyers } \\
\text { govtandoth s } \\
\text { _cons }\end{array}$ & $\begin{array}{r}-9.287332 \\
-1.612052 \\
-30.17645 \\
-84.61869 \\
106.2121\end{array}$ & $\begin{array}{r}16.16692 \\
9.767793 \\
14.31405 \\
37.6925 \\
16.77725\end{array}$ & $\begin{array}{r}-0.57 \\
-0.17 \\
-2.11 \\
-2.24 \\
6.33\end{array}$ & $\begin{array}{l}0.566 \\
0.869 \\
0.036 \\
0.026 \\
0.000\end{array}$ & $\begin{array}{r}-41.184 \\
-20.884 \\
-58.418 \\
-158.98 \\
73.110\end{array}$ & & $\begin{array}{r}22.61019 \\
17.65992 \\
-1.934647 \\
-10.25093 \\
139.3138\end{array}$ \\
\hline /sigma & 52.83088 & 2.743194 & & & 47.418 & & 58.24323 \\
\hline
\end{tabular}

tobit whodecideshowmuchtose 11 andtowho selfpersonalchoice producersunion buyers govtandotheragencies mktforces, 11

$\begin{array}{lllr}\text { Tobit regression } & \text { Number of obs } & = & 187 \\ & \text { LR chi2(5) } & = & 15.98 \\ \text { Log } 7 \text { ike1ihood }=-999.98947 & \text { Prob }>\text { chi2 } & = & 0.0069 \\ & \text { Pseudo R2 } & = & 0.0079\end{array}$

\begin{tabular}{|c|c|c|c|c|c|c|}
\hline whodecides $\sim 0$ & Coef. & Std. Err. & $\mathrm{t}$ & $P>|t|$ & [95\% conf. & Interva1] \\
\hline $\begin{array}{r}\text { selfperson e } \\
\text { producersu n } \\
\text { buyers } \\
\text { govtandoth } \sim 5 \\
\text { mktforces } \\
\text { _cons }\end{array}$ & $\begin{array}{r}-9.875474 \\
-16.72489 \\
-43.55672 \\
-69.09433 \\
-29.06369 \\
114.0335\end{array}$ & $\begin{array}{r}12.66378 \\
12.16493 \\
15.3943 \\
52.97345 \\
11.01973 \\
13.46179\end{array}$ & $\begin{array}{r}-0.78 \\
-1.37 \\
-2.83 \\
-1.30 \\
-2.64 \\
8.47\end{array}$ & $\begin{array}{l}0.437 \\
0.171 \\
0.005 \\
0.194 \\
0.009 \\
0.000\end{array}$ & $\begin{array}{r}-34.86217 \\
-40.72732 \\
-73.93098 \\
-173.6154 \\
-50.80654 \\
87.47224\end{array}$ & $\begin{array}{r}15.11123 \\
7.277535 \\
-13.18247 \\
35.42674 \\
-7.320826 \\
140.5947\end{array}$ \\
\hline /sigma & 52.05917 & 2.701035 & & & 46.7298 & 57.38854 \\
\hline
\end{tabular}




\section{REFERENCES}

1. Brown, L. (1997) Competitive Marketing, Melbourne: Nelson Publication.

2. Elvira, A. Z. (2016). Value Chain Analysis: A Brief Review, Asian Journal of Innovation and Policy. 5.002:116-128.

3. Fearne, A., Martinez, M. G and Dent, B. (2012). Dimensions of Sustainable Value Chains: Implications for value chain analysis, Supply Chain Management, 17(6), 575-581.

4. Gereffi, G. and R. Kaplinsky (eds.) (2001), the value of value chains, IDS Bulletin, Vol. 32, no. 3.

5. Hellin, J. and Meijer, M. (2006) Guidelines for value chain analysis, Food and Agriculture Organization (FAO). UN Agricultural Development Economics Division.

6. Hisayuki Yoshimoto (2008), ECON 203C: System Models, TA Note 8: Version 2.

7. Humphrey, J. and Schmitz, H. (2008), Inter-firm relationships in Global Value Chains: Trends in Chain Governance and Their Policy Implication. International Journal of Technological Learning, Innovation and Development, 1(3), pp. 258-282.

8. Janet Enumeruke O. (2010). Research Methods and Statistics in Education and Social Sciences. Joja Education Research and Publishers Ltd.

9. National Agricultural Statistics Service (2012) Report.

10. Porter M. E. (1985), Competitive Advantage: Creating and Sustaining Superior Performance, N. York: The Free Press.

11. Steve O. Courage (2017), Soya Beans Farming in Nigeria; how to start and make money, Africa Business Classroom (ABC). 